\title{
LUT
}

University

\section{How Do Practitioners Understand External Platforms and Services? A Grounded Theory Investigation}

\author{
Bazarhanova Anar, Yli-Huumo Jesse, Smolander Kari
}

This is a Author's accepted manuscript (AAM) version of a publication

published by Springer

in Advances in Information Systems Development

DOI: 10.1007/978-3-030-22993-1_7

Copyright of the original publication: ( ) Springer Nature Switzerland AG 2019

Please cite the publication as follows:

Bazarhanova A., Yli-Huumo J., Smolander K. (2019) How Do Practitioners Understand External Platforms and Services? A Grounded Theory Investigation. In: Andersson B., Johansson B., Barry C., Lang M., Linger H., Schneider C. (eds) Advances in Information Systems Development. Lecture Notes in Information Systems and Organisation, vol 34. Springer, Cham

This is a parallel published version of an original publication. This version can differ from the original published article. 


\title{
How Do Practitioners Understand External Platforms and Services? A Grounded Theory Investigation
}

\author{
Anar Bazarhanova, Jesse Yli-Huumo and Kari Smolander
}

\begin{abstract}
In this article, we investigate how practitioners understand external platforms, whose core offering is shared and utilized by a number of heterogeneous and interconnected organizations in an ecosystem. We especially look into situations where organizations wish to extend their own capability instead of building services that extend the functionality of the platform. Such dependencies to external platforms can be envisioned as the contemporary evolution from traditional outsourcing service models. We interviewed twenty-four practitioners from eight IT organizations and discovered a considerable ambiguity in understanding of what are the external platforms utilized by the organizations. We further elaborate that the diversified meanings that various stakeholders give to the concept of external platforms, can hinder efficient communication and may have implications on important strategic decision making.
\end{abstract}

Keywords: External platform $\cdot$ industry platform $\cdot$ ecosystem $\cdot$ dependency $\cdot$ integration

A prior version of this paper has been published in the ISD2018 Proceedings (http://aisel.aisnet.org/isd2014/proceedings2018).

A. Bazarhanova $(\square)$

Aalto University, Espoo, Finland

e-mail: anar.bazarhanova@aalto.fi

J. Yli-Huumo

Aalto University, Espoo, Finland

e-mail: jessey187@gmail.com

K. Smolander

Lappeenranta University of Technology, Lappeenranta, Finland

e-mail: kari.smolander@lut.fi 


\section{Introduction}

There is a growing interest on platform thinking [1, 2], which has resulted in a cumulative knowledge on platform ecosystems and their governance [3-5]. However, there are fewer attempts to investigate the companies that are not dominant players [6-8], but need to integrate to various infrastructures and platforms to sustain or extend their business capabilities [9]. These non-focal firms, from the viewpoint of platforms, are platform-utilizing businesses that do not develop platform capability extensions, have no influence on the platform whatsoever, but depend massively on it.

Our research focus departs from the majority of contemporary platform ecosystems research in two aspects. First, we position non-focal actors - subordinate ecosystem participants that are not in the position of power and control to influence the changes in the ecosystem, at the center of our attention. Second, we are interested in integrations with external platforms - when the core offering of the platform is shared and utilized by a number of heterogeneous actors to build services that extend not the functionality of the platform, but their own capability. For example, the travel management industry has platforms that are jointly established by one or many large organizations and then opened to other businesses of any size. Various infrastructures and platforms are constantly evolving, proliferating and becoming more integrated [10]. Blockchain and Internet-Of-Things will bring integrated platforms that force firms to utilize them without any control of the platforms. As platforms grow bigger and form monopolies, smaller firms are constrained to interact with big players. As scholars [11, 12] put it, the management of an enterprise-wide digital infrastructure is quite impossible to do isolated from wider platform ecosystems. For example a company using Google services will be somewhat dependent on how the Google platform ecosystem evolves. This can be explained as an indirect or cross-side network effect [13], i.e., the more users the platform has, the more valuable it is for platform-utilizing firms. Once firms integrate into a platform ecosystem, they become dependent on the decisions of the platform owner, which is similar to vendor lock-in.

Success of many businesses in the future is dependent on their ability to leverage the power of innovations coming for the outside, which are often global, remote and dynamic. A new breed of outsourcing- the external platform dependency can emerge as a monopoly-like industry platform, integration with which is critical to the thriving of a non-focal actor. An example of public API program shutdown at Netflix shows high volatility of the platform and its boundary resources. The significance of dependencies to external platforms is not yet well understood from the viewpoint of platform users. We address this gap by analyzing how practitioners give meaning to their integrations with external platforms. The objective of our study was to understand how practitioners understand external platforms utilized in their firms. The meanings and definitions of external platforms among stakeholders within and across organizations are interpreted into higher level conceptualizations. Grounded Theory with no a priori hypotheses was used as the inductive research method. 


\section{Background}

\subsection{Platforms}

The notion "platform" is relative to its design, utility and the environment of its use, which could often cause confusion. There are a number of studies on platforms evolution [14, 15] their governance [16], the leadership [17] of big players like Google [18], Amazon [19], Apple [20] and organizational decisions to adopt platform strategies [21].

We adopt the definition of Parker \&Van Alstyne [13] and define a digital platform "as the components used in common across a product family whose functionality can be extended by applications and is subject to network effects" [7, 22]. Gawer \& Cusumano [2] categorize platforms in two predominant types: internal or company-specific platforms, and external or industry-wide platforms. The authors define external platforms as "products, services, or technologies developed by one or more firms, and which serve as foundations upon which a larger number of firms can build further complementaries”. Throughout the manuscript we imply the aforementioned definition, however, narrowing the focus in two critical areas and discussing about so-called shared external platforms. First, the extant literature tends to focus on challenges of platform leaders and their competitors. In this study, we investigate external platforms from the other end i.e., the perspective of non-focal actors. Non-focal actors are ecosystem participants that do not have any control over the offering of an external platform. The second aspect is in the context of platform utilization. Unlike Gawer \& Cusumano [2], that discuss about industry platforms as a base for complementary products development for the platform e.g., solution extensions built on top of SAP platform that can be sold to third parties, we look at non-focal firms that utilize industry platforms for their own needs. An example case is a popular messenger application WeChat, China's App for everything, which operates as a platform for providers of payments, bookings management, transport and other services. There the third-party developers of the platform consciously choose to be non-focal, but their initial business intention is to develop complementary products primarily for their own business.

Double-sided markets where the role of the platform is purely to facilitate exchange or trade, without the possibility for other players to innovate on complementary markets, seem to belong to the supply-chain category. Innovation moves of non-focal actors may be opportunistic at times, due to the need to act fast to tap into new capabilities. Thus, dependencies and long-term consequences created from integrations into platforms are not always fully anticipated. As the relationships between non-focal businesses and platform orchestrators (i.e. owners) can be characterized as asymmetric [23], non-focals are forced to continuously accommodate quick adjustments to changes introduced by platform owners [24]. When the number of reasonable platform choices in the market falls to one or only a few, then that only reasonable choice become the de facto standard, also known as its dominant design [25]. While many scholars study how the dominant design emerges and platforms become industry leaders, in our research we wish to draw attention to the need for the knowledge on how "ordinary" firms interact with them. 


\subsection{Integrations}

The motivation for our work is in line with the problem described by Rolland et al. [11]. They discuss a similar problem in the management of external industry platforms as part of a user organization's (non-focal) digital infrastructure and work processes. The authors suggest that while the studies on platforms utilization from the non-focal perspective are not so prevalent, yet, organizations are increasingly adopting digital platforms, "such as Google's G Suite and Microsoft's SharePoint, as central components of their digital infrastructures to support work processes and innovation efforts" [11]. Organizations can integrate with an external platform to sustain their business when the market is disrupted or to extend their offering by combining various resources. These resources can be attributed to some valuable, rare, inimitable and non-substitutable [26], resources (data), unique competences (knowledge), services (methods and algorithms) and people (customer base). Using the service composability principle software companies might consciously or by chance become dependent on platforms using which they build their innovations.

Semantically, the choice between the concepts of "integrating with" and "integrating into" depend on how equal the two things being integrated are. From perspective of platform owner, all heterogeneous ecosystem participants become part of the ecosystem i.e., integrating the smaller ones into the platform ecosystem. Although non focal ecosystem participants understand their obedient position, zooming in into their innovation habitat, the platform is only one component of their business landscape. When the external platform becomes the infrastructure of the firm, consequently, it might become virtually impossible to substitute or eliminate the integration. Cusumano [27] provides a good illustrative example of actors' integrations with platform ecosystems: real estate agencies or retail shops that build applications that incorporate Google Maps and, therefore, tie their applications to Google's platform. When firms plan to integrate into a global, multinational and remote platform, their relationships can hardly be called a partnership. Agreements and terms of service may include some standard performance metrics like service availability and response time, but rarely assure responsibility, continuity and business decisions-driven changes. Success of non-focal firms is dependent on their abilities to leverage the platform offering and their organizational response strategies. Managing external platforms while organizations are increasingly adopting them as part of their infrastructures is a costly and highly uncertain process [11]. As supported by Rolland et al. [11], the research from non-focal viewpoint is almost nonexistent, yet, it has a high potential of gathering important insights for research and practice.

\section{Methods}

It is important to state that our study commenced with a different research question than we are reporting in this manuscript. Initially, we wanted to investigate how the utilization of external platforms can be explained. We then proceeded with data collection as explained in the paragraph below. During the data collection and analysis we recognized the emerging phenomena - divergent understanding among interviewees. Thus, 
the findings we report in this manuscript answer the following research question: How do practitioners understand external platforms utilized in their firms? In order to explore the understanding of practitioners on external platforms, we used the Grounded Theory method [28]. We chose this qualitative theory-forming method as the area of interest is complex and the perspective is unexplored. An interpretive research methodology also allows to investigate a phenomenon within its real-life context.

We arranged meetings with interviewees for data collection, formulated initial research objectives and interview themes. We chose an exploratory focus with no specific theory in mind. Most of the interviews were conducted together by the first two authors. While the data analysis and coding were done primarily by the first author, a number of discussions on theoretical concepts elicitation were held together with all authors. We had discussions with 24 industry experts from 8 organizations, see Table 1.

Table 1. Interviewees

\begin{tabular}{|c|c|c|}
\hline ID & Industry & Position \\
\hline$\overline{\mathrm{A} 1}$ & Telecom & Head of Enterprise Architecture \\
\hline A2 & Telecom & Director, Corporate Solutions \\
\hline A3 & Telecom & Development Manager, Corporate solutions \\
\hline A4 & Telecom & Chief Digital Officer \\
\hline A5 & Telecom & Manager, Data services \\
\hline A6 & Telecom & Development Manager \\
\hline A7 & Telecom & Head of Online Performance \\
\hline A8 & Telecom & Vice President, Broadband and Entertainment Business \\
\hline A9 & Finance & Head of Point of Sale, Service Engineering \\
\hline A10 & Finance & Head of Quality Assurance, Merchant Services \\
\hline A11 & Finance & SVP Digital Innovation \\
\hline A12 & Finance & Senior Manager, Digital Practices \\
\hline A13 & Ministry & Development Manager \\
\hline A14 & Ministry & Main Architect \\
\hline A15 & Ministry & Service Manager \\
\hline A16 & ISV & Development Manager \\
\hline A17 & Research & Main Architect \\
\hline A18 & Research & Architect \\
\hline A19 & Research & IT Services Manager \\
\hline A20 & ISV1 & CEO \\
\hline A21 & ISV2 & CEO \\
\hline A22 & ISV2 & СTO \\
\hline A23 & Municipality & Project Manager, Head of e-services Program \\
\hline A24 & Municipality & Main Architect \\
\hline
\end{tabular}


The organizations vary by sectors: telecommunications, finance, software development, research, municipalities and ministries. The company sizes vary from 10 to 40000 employees operating mostly in Finland and the Nordics. The selection of companies was based on convenience sampling.

\subsection{Data Collection and Analysis}

We planned the interviews as semi-structured, more in the form of a discussion. We used the interview instrument as a guide to discuss the topics such as "external platform utilization examples in the company", "reasons for the integration with this platform", "problems and benefits of this integration". The interviews were conducted during the period of 6 months and lasted between 35 minutes and 95 minutes. The interviews followed the funnel model principle [29] - from open to more specific questions. Each interview began by asking general questions regarding the position of the interviewees, their background, experience and the projects they are managing, and then, proceeding to the questions on external platforms identification. The list of interviewees with their corresponding organization and positions is provided in Table 1 . The interviews were conducted face-to-face at company facilities, except one video-conference call with A11 and A22.

We analyzed the gathered data with a qualitative data coding and analysis tool, Atlas.ti. The first step of Grounded Theory [28] was open coding, where we went line-byline in each of 24 interviews and labelled the pieces of information. For example, we coded the quote "but we have almost all of the platforms somehow in-house" - as attributing the external platform to its physical location outside the premises of the company. We extracted quotes from all transcriptions that we believed were relevant regarding the research topic such as the names of the platforms that interviewees identified as external platforms. The next step was axial coding, where we systematically browsed through the open codes to find the relations between them, merged or disaggregated relevant concepts.

Table 2 presents the examples of what the interviewees identified as "external platform” - open coding data (column 2), labelled with the corresponding axial coding indicative concept (column 3) e.g., physical location, lack of customization, outsourced solution. Our goal was to let the understanding of the phenomenon emerge from the interviews. Finally, in selective coding [30] we selected and described the central phenomenon, "external platforms interpretations" in the light of core categories. The goal was to integrate and refine the degree to which a concept varies in its dimensions. Excerpts in Table 2 are provided as illustrative examples. By merging and recombining the labels from the third column we discuss higher level conceptualizations below. 
Table 2. Representative excerpts from interviews are presented in column 2. Axial codes in the column 3 are based on the corresponding interpretations and explanations of the interviewees.

\begin{tabular}{|c|c|c|c|}
\hline ID & Position & External platforms identified examples & $\begin{array}{l}\text { External platform is pri- } \\
\text { marily a/an }\end{array}$ \\
\hline A1 & Architect & $\begin{array}{l}\text { "We have almost all of the platforms } \\
\text { somehow in-house","SalesForce would } \\
\text { be that kind of [external] platform" }\end{array}$ & $\begin{array}{l}\text { Instance physically running } \\
\text { externally } \\
\text { Instance from big vendors }\end{array}$ \\
\hline A2 & $\begin{array}{l}\text { Director, Corpo- } \\
\text { rate Solutions }\end{array}$ & $\begin{array}{l}\text { "You can name any brand and most } \\
\text { likely we have it" }\end{array}$ & Instance from big vendors \\
\hline A3 & $\begin{array}{l}\text { Development } \\
\text { Manager, Corpo- } \\
\text { rate solutions }\end{array}$ & Google Azure & $\begin{array}{l}\text { Instance for service devel- } \\
\text { opment, Instance from big } \\
\text { vendors }\end{array}$ \\
\hline A4 & $\begin{array}{l}\text { Chief Digital Of- } \\
\text { ficer }\end{array}$ & SAP CRM solution & Instance from big vendors \\
\hline A5 & $\begin{array}{l}\text { Manager, Data } \\
\text { services }\end{array}$ & $\begin{array}{l}\text { "Our BSS solutions, is more or less like } \\
\text { a cloud service, but more like a dedi- } \\
\text { cated cloud service of ours, and from } \\
\text { my point of view is not a real cloud ser- } \\
\text { vice” }\end{array}$ & $\begin{array}{l}\text { Instance for service devel- } \\
\text { opment, instance that is not } \\
\text { under direct control }\end{array}$ \\
\hline A6 & $\begin{array}{l}\text { Development } \\
\text { Manager }\end{array}$ & $\begin{array}{l}\text { "Because when you have this kind of } \\
\text { monopoly as [name] have had, the } \\
\text { problem is that there is no driving force } \\
\text { to develop it" }\end{array}$ & The only choice platform \\
\hline A7 & $\begin{array}{l}\text { Head of Online } \\
\text { Performance }\end{array}$ & $\begin{array}{l}\text { "Whether that is explicitly external, or, } \\
\text { a service that we buy from a company } \\
\text { and we integrate into , there is, tons of, } \\
\text { different types of providers that we use } \\
\text { for, say, uh, order handling, billing sys- } \\
\text { tems" }\end{array}$ & Black box service \\
\hline A8 & $\begin{array}{l}\text { VP, Broadband } \\
\text { and Entertain- } \\
\text { ment Business }\end{array}$ & Content Delivery Platforms & Instance from big vendors \\
\hline A9 & $\begin{array}{l}\text { Head of Point of } \\
\text { Sale, Service En- } \\
\text { gineering }\end{array}$ & $\begin{array}{l}\text { ECR machines, ERP systems, Master- } \\
\text { Card, Visa, hardware i.e. payment ter- } \\
\text { minals }\end{array}$ & $\begin{array}{l}\text { Instance that is not devel- } \\
\text { oped/maintained by them, } \\
\text { IT outsourcing, Instance } \\
\text { from big vendors }\end{array}$ \\
\hline A10 & $\begin{array}{l}\text { Head of Quality } \\
\text { Assurance, Mer- } \\
\text { chant Services }\end{array}$ & AWS Real-Time Analytics & Black box service \\
\hline A11 & $\begin{array}{l}\text { SVP Digital In- } \\
\text { novation }\end{array}$ & $\begin{array}{l}\text { "But we are not using any AWS, not } \\
\text { Google for production services or other } \\
\text { kind of open platform trends. I think } \\
\text { there is a fair question if we want to ex- } \\
\text { tend something on top of something, }\end{array}$ & $\begin{array}{l}\text { Instance for service devel- } \\
\text { opment }\end{array}$ \\
\hline
\end{tabular}


why should we do that. How much

value can that bring us?”

A12 Senior Manager, "That is not really a platform but a ser- Instance from big vendors Digital Practices vice out of the platform"

A13 Development "What is the role of Facebook in gov- Not under direct control
Manager ernmental organizations?"

A14 Main Architect "Security issues, so we do not really Instance that is not develbuy that as a service or rely on external oped by them, Instance service providers" from big vendors

\begin{tabular}{llll}
\hline A15 & Service Manager & SAP & Instance from big vendors \\
\hline A16 & Development & "Something like that or, or whatever & Instance physically running
\end{tabular}
Manager product that is, that is they are using via externally web”

\begin{tabular}{|c|c|c|c|}
\hline A17 & Main Architect & $\begin{array}{l}\text { Microsoft, Google, HR platforms, bill- } \\
\text { ing, invoicing services }\end{array}$ & Instance from big vendors, \\
\hline A18 & Architect & Billing platform & $\begin{array}{l}\text { Instance physically running } \\
\text { externally, }\end{array}$ \\
\hline A19 & $\begin{array}{l}\text { IT Services Man- } \\
\text { ager }\end{array}$ & Capability level platforms & $\begin{array}{l}\text { Receiving as a service, IT } \\
\text { outsourcing }\end{array}$ \\
\hline A20 & CEO & Google Transit & $\begin{array}{l}\text { That is not developed and } \\
\text { maintained by them }\end{array}$ \\
\hline A21 & CEO & MailChimp, Trello, Office 360 & $\begin{array}{l}\text { Instance that is not under } \\
\text { direct control }\end{array}$ \\
\hline A22 & СТO & eID platform & The only choice platform \\
\hline A23 & $\begin{array}{l}\text { Project Manager, } \\
\text { Head of e-ser- } \\
\text { vices Program }\end{array}$ & eID platform & $\begin{array}{l}\text { The only choice platform, } \\
\text { Instance from big vendors }\end{array}$ \\
\hline A24 & Main Architect & $\begin{array}{l}\text { "There is always some learning to do, } \\
\text { and some problems usually arise. Sud- } \\
\text { denly you find that there's some integra- } \\
\text { tions to make and some systems to up- } \\
\text { grade, they don't support certain proto- } \\
\text { cols" }\end{array}$ & $\begin{array}{l}\text { Instance with a limited cus- } \\
\text { tomization }\end{array}$ \\
\hline
\end{tabular}

\section{$4 \quad$ Findings}

One of the first striking observations we noticed was that almost each interviewee gave different examples of what they considered to be external platforms. Even the respondents from the same organization suggested different cases: A17 discussed about the services from Google, Microsoft and Dropbox; A18 considered their Platform as a Service (PaaS) for billing as the most suitable case, whereas A19 managed to interpret the external platform phenomenon immediately. Table 2 demonstrates example excerpts. The differentiation between dedicated *aaS models (i.e., a collective term that refers to 
the delivery of a centrally hosted service over a network and on a subscription basis) and external platforms was particularly challenging for business-unit professionals. Obviously, the difficulties in distinguishing the specifics of deployment and service models may have been due to incomplete technical expertise; yet, most of the interviewees have had managing and executive positions in organizations that operate in technology industry.

Table 3. Mapping of axial codes to selective coding categories

\begin{tabular}{|c|c|c|}
\hline ID & Axial coding & Selective coding categories \\
\hline A1 & Instance physically running externally & Externally deployed \\
\hline A2 & Instance from big vendors & Externally developed, deployed \\
\hline A3 & $\begin{array}{l}\text { Instance for service development, Instance } \\
\text { from big vendors }\end{array}$ & Externally developed, deployed \\
\hline A4 & Instance from big vendors & Externally developed, deployed \\
\hline A5 & $\begin{array}{l}\text { Instance for service development, instance } \\
\text { that is not under direct control }\end{array}$ & $\begin{array}{l}\text { Externally developed, managed, de- } \\
\text { ployed }\end{array}$ \\
\hline A6 & The only choice platform & $\begin{array}{l}\text { Externally }\{\text { managed }+ \text { developed }+ \\
\text { deployed }\}+ \text { shared use }\end{array}$ \\
\hline A7 & Black box service & Externally managed \\
\hline A8 & Instance from big vendors & Externally developed, deployed \\
\hline A9 & $\begin{array}{l}\text { Instance that is not developed/maintained } \\
\text { by them, IT outsourcing }\end{array}$ & $\begin{array}{l}\text { Externally developed; managed, de- } \\
\text { ployed }\end{array}$ \\
\hline A10 & Black box service & Externally managed \\
\hline A11 & Instance for service development & Externally deployed, developed \\
\hline A12 & Instance from big vendors & Externally developed, deployed \\
\hline A13 & Not under direct control & Externally managed, deployed \\
\hline A14 & $\begin{array}{l}\text { Instance that is not developed by them, In- } \\
\text { stance from big vendors }\end{array}$ & $\begin{array}{l}\text { Externally developed, deployed, man- } \\
\text { aged }\end{array}$ \\
\hline A15 & Instance from big vendors & Externally developed, deployed \\
\hline A16 & Instance physically running externally & Externally deployed \\
\hline A17 & Instance from big vendors & Externally developed, deployed \\
\hline A18 & Instance physically running externally, & Externally deployed \\
\hline A19 & Receiving as a service, IT outsourcing & Externally managed, deployed \\
\hline A20 & $\begin{array}{l}\text { That is not developed and maintained by } \\
\text { them }\end{array}$ & Externally developed, managed \\
\hline A21 & Instance that is not under direct control & Externally managed, developed \\
\hline A22 & The only choice platform & $\begin{array}{l}\text { Externally }\{\text { managed }+ \text { developed }+ \\
\text { deployed }\}+ \text { shared use }\end{array}$ \\
\hline A23 & $\begin{array}{l}\text { The only choice platform, Instance from } \\
\text { big vendors }\end{array}$ & $\begin{array}{l}\text { Externally } \text { \{managed }+ \text { developed }+ \\
\text { deployed }+ \text { shared use }\end{array}$ \\
\hline A24 & Instance with a limited customization & $\begin{array}{l}\text { Externally }\{\text { managed }+ \text { developed }+ \\
\text { deployed }\}+ \text { shared use }\end{array}$ \\
\hline
\end{tabular}


An example excerpt below suggests that external platforms are seen as something the organization did not develop, i.e., software products from various vendors. In contrast, tech-savvy professionals could clearly recognize the distinctions of external platforms and the types of dependencies to them.

A2: "Do you know how many external platforms we have? We do not develop anything ourselves."

Another response below is from an informed interviewee critically reflecting on the differences between dedicated instances of external platforms (Salesforce, SaaS) and a shared external platform (eBay for merchants).

A5: “our BSS solutions, is more or less like a cloud service, but more like a dedicated cloud service for us [Telco], and from my point of view it is not a real cloud service [external]."

To summarize, we identified four categories of disparate interpretations on external platforms. Table 3 presents the mapping of axial coding to selective coding categories and in the section below we explain each category (i.e., dimension) of practitioners understanding on external platforms.

\subsection{Different Dimensions of External Platforms}

Externally Deployed. The most common understanding of external platform is the physical deployment of the underlying physical infrastructure where the platform is hosted. A platform was understood to be external when it is not running in house, but outside of the organization's premises.

A1: "... the definition what is the external platform or ecosystem and so on, but we have almost all of the platforms somehow in-house. We have to keep them in-house, we have our own datacenters, and we would like to keep those platforms in our own datacenters as well. So lots of stuff is happening in our own datacenters."

Hence, most interviewees assumed any service from the cloud, i.e., with network access, to be external. In a way, it is a valid statement, but in our interviews we explained that *aaS service model may imply a dedicated instance for each user organization, where there is a limited, but some control over the instance. For example, organizations may utilize several cloud service platforms that are remote by definition, but there is a degree of control over the dedicated instance that the utilizing company has. This category reflects one of the characteristics of the cloud computing deployments models - availability over the network and accessing the resources remotely via the Internet.

Externally Developed. The clear majority of practitioners associated any software system with the origin of predominantly big vendors e.g., SAP, Salesforce, Oracle, SAS, as external platform by default. 
A2: "You can almost name whatever brand we probably use it somehow. Because of our large portfolio.”

The above is an example-reply when the interviewee was asked about the cases of external platforms used in the organization. Partially, the confusion might have been caused by commercial offer descriptions where the terms may be misused for marketing purposes.

A12: "I really don't think we are using any platforms currently. The thing is every software would like to call itself a software platform. So naturally, if you were using Oracle Database, Oracle would call it a platform. We are using Oracle, but we are using the database. For security reasons we are running all of our product lines all by ourselves."

Such concepts misuse may lead to ambiguous understanding among vendors, their customers and management what the offering really is [31].

A17: "Another problem, our support is confronted basically every three month when users call and ask how to use the functionality ... a new feature in the [platform]. That is setting a dramatic user support problem for user organization. Microsoft is glad to sell us a service ... It is not cheap, 80000 euros per year for a subscription, to be notified about new features they are about to release."

Externally Managed. This category includes two subcategories which we integrate for simplicity reasons. One abstraction the respondents affiliated with external service platforms were the black box services developed for the organization. Nowadays, organizations prefer to recruit individual developers or small supplier-companies to build and maintain the systems for the organization to solve some specific problems. Interviewees referred to them as something they do not want or/and need to know how it works. Examples include billing, invoicing services and other business intelligence tools.

As a second abstraction is, interestingly, even when only the operation and maintenance of a service was outsourced to a subcontractor or partner firm, the service was mentioned to be external too. Interviewees from medium-sized and large organizations characterized their relations with service providers as "partnerships", regardless the size of partners, implying a horizontal relationship mind-set. When choosing vendors or outsourcing partners they prefer to exploit existing network of partners. Respondents justify these strategic preferences by the degree of the power they are able to impose on long-term partners.

A4: "For us, the roadmap of a provider is important. Because of single point of failure in a way, if it's going to be Google for example, let's just for fun say we use it. And if everybody integrates to that, you now have to ask who owns the ecosystem? The one who owns it that, owns the API, owns the ecosystem, they can do all the changes. If they want to change the API, they can do it like this and everybody has to, you know, just accept it or stay out of there." 
Externally \{Deployed + Developed + Managed $\}+$ Shared. Lastly, interviewees acknowledge the existence of some voluntary-compulsory dependencies to certain services provided by other firms. These can be legal enforcements or constraints imposed by industry monopolies [32].

A17: "If we go outside of this scope: what you refer is our current subscription to Microsoft, Amazon and Google. Where we are in a passenger seat and we don't know where we are going. The challenge is that every 3 months there are new changes coming in, which are not necessarily compliant with Finnish laws."

Other examples include public digital infrastructures such as X-Road [33], an open source data exchange layer solution that enables organizations to exchange information over the Internet. This metaphor reflects the notion of external platforms we introduce in this article; i.e., the dependencies in business-critical operations that were not possible to avoid. In case of such integrations, all interviewees expressed their preference to have a number of competing platforms than a full-fledged "one-stop shop" platform. The categories we identified are not mutually-exclusive and disconnected. On the contrary, the first three categories emphasize different dimensions of a bigger concept of external platforms.

\section{Discussion}

External platforms utilization, as well as cloud services adoption or systems maintenance outsourcing, can be seen as a means to manage the complexity [34]. Schneider and Sunyaev [35] define a cloud-sourcing decision as "the decision of the organization to adopt and integrate cloud services from external providers into their IT landscape, that is, the customer organization's assessment of cloud computing offerings from one or more providers in any form of service model (IaaS, PaaS, SaaS) or deployment model (public, private, community, hybrid)".

We commit to the view of IT outsourcing as a predecessor of cloud computing models and extend this continuum with external platforms. Based on their comparison of Cloud Computing with IT outsourcing [35] we reuse the determinant factors (Table 3, Column 1) to contrast Cloud Computing (Table 3, Column 2) and IT outsourcing (Table 3, Column 3) with external platforms. The categories from our findings descriptively correspond to the cloud sourcing models presented in Table 3: externally developed primarily (but not exclusively) refer to cloud computing models, externally managed to IT outsourcing, and externally deployed to all. Inconsistencies in understanding may represent idiosyncratic differences in the perceptions of interviewees and reflect the contextual differences of priorities among key personnel e.g., top management and enterprise architects. The confusion may also be due to lack of comprehensive clarifications and taxonomies. 
Table 4. External platforms as IT sourcing evolution, adapted and shortened from [35]. In italics are the essential categories from our analysis.

\begin{tabular}{|c|c|c|c|}
\hline & $\begin{array}{l}\text { Primarily externally } \\
\text { managed; } \\
\text { IT outsourcing in [35] }\end{array}$ & $\begin{array}{l}\text { Primarily externally de- } \\
\text { veloped; } \\
\text { Cloud computing in [35] }\end{array}$ & Shared external platforms \\
\hline Decision & $\begin{array}{l}\text { Vendor selection prior } \\
\text { to decision on degree of } \\
\text { outsourcing } \\
\text { Top management as de- } \\
\text { cision maker }\end{array}$ & $\begin{array}{l}\text { Vendor selection bound } \\
\text { to product selection } \\
\text { SaaS by business depart- } \\
\text { ment, IaaS/PaaS by IT } \\
\text { department }\end{array}$ & $\begin{array}{l}\text { The platform is valuable, } \\
\text { rare, inimitable and non- } \\
\text { substitutable enough to rep- } \\
\text { resent nearly the only rea- } \\
\text { sonable choice } \\
\text { Top management as deci- } \\
\text { sion maker }\end{array}$ \\
\hline $\begin{array}{l}\text { Asset speci- } \\
\text { ficity }\end{array}$ & $\begin{array}{l}\text { Custom-tailored IT- } \\
\text { services, may include } \\
\text { software development, } \\
\text { datacenter or desktop } \\
\text { maintenance, help desk }\end{array}$ & $\begin{array}{l}\text { Standardized software } \\
\text { (SaaS) or cloud infra- } \\
\text { structure (IaaS/PaaS) }\end{array}$ & $\begin{array}{l}\text { Standardized, dynamic } \\
\text { platform offering with vol- } \\
\text { atile boundary resources } \\
\text { (APIs, SDK, contracts) }\end{array}$ \\
\hline $\begin{array}{l}\text { Customiza- } \\
\text { bility }\end{array}$ & $\begin{array}{l}\text { Individually negotiated } \\
\text { configurations }\end{array}$ & $\begin{array}{l}\text { At a minimum, some lim- } \\
\text { ited user-specific applica- } \\
\text { tion configuration set- } \\
\text { tings }\end{array}$ & $\begin{array}{l}\text { Non-existent configura- } \\
\text { tional tuning capability at } \\
\text { any of OSI stack layers }\end{array}$ \\
\hline $\begin{array}{l}\text { User-to-sys- } \\
\text { tem utiliza- } \\
\text { tion cardinal- } \\
\text { ity }\end{array}$ & $\begin{array}{l}\text { One-to-one relationship } \\
\text { tions and individual syst } \\
\text { organization has exclus } \\
\text { stance }\end{array}$ & $\begin{array}{l}\text { between user-organiza- } \\
\text { em instance, i.e. each user- } \\
\text { ive access to its own in- }\end{array}$ & $\begin{array}{l}\text { many**one relationship, } \\
\text { i.e. all user-organizations } \\
\text { reuse the same platform in- } \\
\text { stance }\end{array}$ \\
\hline $\begin{array}{l}\text { Externally } \\
\text { deployed }\end{array}$ & Outside or in-premises & $\begin{array}{l}\text { Usually outside, broad } \\
\text { network access and de- } \\
\text { pendence }\end{array}$ & Outside \\
\hline Ownership & $\begin{array}{l}\text { Varies with the type of } \\
\text { outsourcing }\end{array}$ & $\begin{array}{l}\text { Ownership of the data } \\
\text { stored in the system and } \\
\text { the rights to get it back } \\
\text { belongs usually to the } \\
\text { customer }\end{array}$ & $\begin{array}{l}\text { The platform, its deriva- } \\
\text { tives and sometimes even } \\
\text { the associated data are } \\
\text { owned by the provider }\end{array}$ \\
\hline $\begin{array}{l}\text { Contractual } \\
\text { mode }\end{array}$ & $\begin{array}{l}\text { Usually long-term stra- } \\
\text { tegic partnerships pre- } \\
\text { ferred }\end{array}$ & Standardized terms of use & $\begin{array}{l}\text { Non-negotiable SLAs, stra- } \\
\text { tegic decisions on platform } \\
\text { development or service dis- } \\
\text { continuity, interfaces avail- } \\
\text { ability are made by pro- } \\
\text { vider }\end{array}$ \\
\hline $\begin{array}{l}\text { Substitutabil- } \\
\text { ity or aban- } \\
\text { donment op- } \\
\text { tions [36] }\end{array}$ & $\begin{array}{l}\text { Moderate to high num- } \\
\text { ber of alternatives } \\
\text { Outsourcing market is } \\
\text { well established with } \\
\text { numerous experienced } \\
\text { providers }\end{array}$ & $\begin{array}{l}\text { Moderate to high number } \\
\text { of alternatives } \\
\text { Volatile and immature } \\
\text { market }\end{array}$ & $\begin{array}{l}\text { Number of alternatives is } \\
\text { non-existent or extremely } \\
\text { limited } \\
\text { Market in its nascent stage, } \\
\text { uncertain legal issues }\end{array}$ \\
\hline
\end{tabular}


Examples Software development SaaS e.g. Salesforce, subcontracting
CRM integration with Facebook, Google AdWords in marketing business, Applications based on Distributed Ledger Technology

\subsection{Implications}

Diversified answers of interviewees point to divergent notions of external platform among practitioners. Moreover, even traditional service models are confused with each other. Our findings indicate the absence of agreement within community of practitioners on various criteria of systems utilized in their organizational operations. The ambiguity is, perhaps, amplified because of difficulties to define what the platform is. The same level of comprehension on the phenomenon of integrations and dependencies with external platforms is crucial in conversations between architects, IT and business unit professionals. Improper differentiation can potentially lead to inaccurate communication of problems and opportunities, their evaluation and cause misleading judgments. One can argue that the dependency to external platforms are rare, because organizations hesitate to outsource business-critical resources or functions [31]. Obviously, no business will take the risk of putting its business-critical applications in the cloud without a very strong assurance of access to those applications and associated data. However, the utilization of intangible resources e.g., technological or managerial knowledge [37] or tangible IT resources i.e., software, data [38] coming from the outside is more common. As scholars note [39, 40], innovation shifts do not "happen teleologically, but rather though gradual and locally emergent evolutions". Cost advantages, flexibility and competitive advantages made IT sourcing, as one of the main strategic decision concepts in modern businesses [35]. In our work, we denote the integrations with external industry platforms as a contemporary emerging service model.

Dynamic capabilities of a firm can be defined as the ways to manipulate resource configurations to gain a competitive advantage [41]. They include strategic decision making, alliancing, and product and service innovation. There are studies on the relation of cloud computing solutions adoption into the internal IT capabilities of the company, and the results call for more research to confirm whether the lack of internal IT capabilities as a driver for SaaS adoption and inhibitor for IaaS/PaaS [35]. Benlian [42] provides evidence on the differences regarding the perceived relative performance of different delivery models among IS managers of SMEs compared to large enterprises $[31,35]$. Examples of integrations with shared external platforms seemed to be rarer in larger organizations we interviewed. The mental model of managers in incumbent and large companies may be seen as trying to avoid dependencies they cannot control, preserve power integrity and gain more power and secure their position by carefully establishing alliance partner relationships. Exceptional cases are when established companies allow the use of external platforms for non-critical activities or as complementary solutions. For example, the use of social media platforms for boarding tickets distribution by airline companies where e.g. Facebook's Messenger is only one option among other distribution channels (e.g. email, sms). 
Our findings may also be a starting point for further theorizing on external platform adoption tendency. Organizations in nascent highly-dynamic markets often follow entrepreneurial modes of behavior strategies [43], i.e., they are fast decision makers, open to experimenting and value newly acquired knowledge. Studies on cloud computing adoption find that "smaller and medium-sized firms are generally more prone to adopt on-demand outsourcing options for obtaining fast access to valuable IT resources and capabilities” [31, 42]. It is possible that such firms are more pragmatic in leveraging innovations coming from the outside. Small and young firms may understand that they are undisguised to innovation threats from tech giants as they do not possess required capabilities and resources. Such organizations, therefore, can be seen unprejudiced about their power and control disadvantage and, consequently, fast in adopting innovations from global providers. Due to the lack of resources and power they make decisions based on facts and features and what actually the platform capability is. On the other hand, incumbent organizations that operate in moderately-dynamic markets with stable industry structures, tend to follow linear and incremental changes. These organizations usually value and try to leverage existing, cumulative knowledge, and therefore they follow risk mitigation practices [41] to avoid integrations they cannot fully control. These propositions, however, need to be investigated in future research with a larger sample.

\subsection{Limitations and Future Research}

As with any qualitative inquiry, our study has three potential validity threats. We follow the validity dimensions of Maxwell [44] in qualitative research. First, descriptive validity threat is eliminated by recording and transcribing each interview in true verbatim, to ensure the factual accuracy of the data. As qualitative researchers are not interested in solely describing the reality, but concerned what the phenomenon under study mean, there is an interpretative validity threat. Although there is no "in principle access to data that would unequivocally address this threat to validity”, we attempted to construct our findings closely grounded in the language used by interviewees, their own words and concepts [44]. We used mostly open-ended questions to allow respondents to elaborate on answers and avoided using leading questions to get a desired response. In fact, we view non-consistent interpretations among respondents as findings. The next validity threat is theoretical, which is not concerned with factual accuracy and consensus, but rather with the legitimacy of the applications of the concepts to the phenomena and the validity of causal relationships among them. Here, the choice of Grounded Theory with no a priori theory in mind and its continuous interplay of data collection and analysis along with incremental open, axial and selective coding procedure spanning for several months has proved its usefulness. This ensured that the constructs identifications and their application to the data are not biased and the patterns identified were (as much as possible) theoretically saturated and different types of relations between concepts are identified. Next, as with any other qualitative study we cannot claim the internal or external generalizability of the findings as such, but rather their analytical transferabil- 
ity ex-tended to other cases. Moreover, the generalization in qualitative research implies that the phenomenon identified should be also identified in other settings and cases, but, perhaps, with different results i.e., new interpretations on external platforms.

An important future research agenda can be to identify the emergent conditions of external platforms-based dependencies; empirically-valid risks mitigation practices along with benefits realization would form a fundamental understanding of the phenomenon. Another important research direction can be the role of APIs as boundary resources between non-focal actors and platforms, including API ecosystems evolution and what it means for different industries and enterprise strategies [45]. The state of the practice indicates that the external dependencies among more established organizations are at its nascent stage - firms have mostly *aaS types of relations and only few external platforms. Part of the difficulty in distinguishing these approaches is that they often coincide in practice and are neglected in theory. Proper visualization and modelling of enterprise information and IS architecture could improve the practice. Nowadays, organizations seem to be much consumed and involved in transforming their own products into platforms i.e., "platformization", so that the external dependencies might be neglected, which could lead to twisted strategic maneuvers, or missed opportunities.

\section{Conclusions}

From our interviews with 24 practitioners we found that practitioners across units and sectors perceive the notion of external industry platforms differently, confusing them within service and deployment models. External platforms, from the understanding of practitioners, may primarily refer to the ones which are externally deployed, developed, managed. A combination of three attributes together with a multiple simultaneous use of the platform refers to shared external platform-based dependence, i.e., monopolylike platforms. We also anticipate that integrations with external platforms could be more common among entrepreneurial firms in nascent markets and that established organizations are less open to have such dependencies and give up the control. However, this proposition needs to be investigated and developed further in future research.

Acknowledgements. This research was funded by Academy of Finland (304439).

\section{References}

1. Boudreau, K.J., Hagiu, A.: Platform Rules: Multi-Sided Platforms as Regulators. Platf. Mark. Innov. 163-191 (2009)

2. Gawer, A., Cusumano, M.A.: Industry platforms and ecosystem innovation. J. Prod. Innov. Manag. 31, 417-433 (2014)

3. Eisenmann, T.R., Parker, G., Van Alstyne, M.: Opening Platforms: How, When and Why? Platf. Mark. Innov. 131-162 (2009)

4. Huber, T.L., Kude, T., Dibbern, J.: Governance Practices in Platform Ecosystems: Navigating Tensions Between Cocreated Value and Governance Costs. Inf. Syst. Res. (2017) 
5. Tiwana, A.: Platform Ecosystems: Aligning Architecture, Governance, and Strategy. Morgan Kaufmann Publishers Inc., San Francisco, CA, USA (2014)

6. Ghazawneh, A., Henfridsson, O.: Balancing platform control and external contribution in third-party development: The boundary resources model. Inf. Syst. J. 23, 173-192 (2013)

7. Huang, P., Ceccagnoli, M., Forman, C., Wu, D.: When Do ISVs Join a Platform Ecosystem? Evidence from the Enterprise Software Industry. ICIS 2009 Proc. 1-18 (2009)

8. Lindgren, R., Eriksson, O., Lyytinen, K.: Managing identity tensions during mobile ecosystem evolution. J. Inf. Technol. 30, 229-244 (2015)

9. Selander, L., Henfridsson, O., Svahn, F.: Capability search and redeem across digital ecosystems. J. Inf. Technol. 28, 183-197 (2013)

10. Evans, P.C., Gawer, A.: The rise of the platform enterprise: a global survey. (2016)

11. Rolland, K.H., Mathiassen, L., Rai, A.: Managing Digital Platforms in User Organizations: The Interactions Between Digital Options and Digital Debt. Inf. Syst. Res. (2018)

12. Yoo, Y., Henfridsson, O., Lyytinen, K.: The new organizing logic of digital innovation: An agenda for information systems research. Inf. Syst. Res. 21, 724-735 (2010)

13. Parker, G., Van Alstyne, M.: Innovation, openness, and platform control. Manag. Sci. (2017)

14. Henfridsson, O., Bygstad, B.: The Generative Mechanisms of Digital Infrastructure Evolution. MIS Q. 37, 907-931 (2013)

15. Tilson, D., Lyytinen, K., Sørensen, C.: Digital infrastructures: The missing IS research agenda. Inf. Syst. Res. 21, 748-759 (2010)

16. Jansen, S., Cusumano, M.A.: Defining software ecosystems: a survey of software platforms and business network governance. Softw. Ecosyst. Anal. Manag. Bus. Netw. Softw. Ind. 13, (2013)

17. Gawer, A., Cusumano, M.A.: How Companies Become Platform Leaders. MIT Sloan Manag. Rev. 49, 28-35 (2008)

18. Karhu, K., Tang, T., Hämäläinen, M.: Analyzing competitive and collaborative differences among mobile ecosystems using abstracted strategy networks. Telemat. Inform. 31, 319-333 (2014)

19. Venkatraman, V.N., El Sawy, O.A., Pavlou, P., Bharadwaj, A.: Theorizing Digital Business Innovation: Platforms and Capabilities in Ecosystems. Fox Sch. Bus. Res. Pap. 15080. 1-36 (2014)

20. Eaton, B., Elaluf-Calderwood, S., Sørensen, C., Yoo, Y.: Distributed Tuning of Boundary Resources: the Case of Apple's iOS Service System. MIS Q. 39, 217-243 (2015)

21. Ghanam, Y., Maurer, F., Abrahamsson, P.: Making the leap to a software platform strategy: Issues and challenges. Inf. Softw. Technol. 54, 968-984 (2012)

22. Boudreau, K.: Does Opening a Platform Stimulate Innovation? The Effect on Systemic and Modular Innovations, https://ssrn.com/abstract=913402, (2007)

23. Pfeffer, J., Salancik, G.R.: The external control of organizations: A resource dependence perspective. Stanford University Press (2003)

24. Altman, E.J.: Dependency challenges, response strategies, and complementor maturity: Joining a multi-sided platform ecosystem. Working paper (2016)

25. Baldwin, C.Y., Clark, K.B.: Design Rules: The Power of Modularity. Acad. Manage. Rev. 26, 471-471 (2000) 
26. Barney, J.: Firm Resources and Sustained Competitive Advantage. J. Manag. 17, 99-120 (1991)

27. Cusumano, M.: Cloud computing and SaaS as new computing platforms. Commun. ACM. 53, 27 (2010)

28. Glaser, B., Strauss, A.: The discovery of grounded theory. 1967. Weidenfield Nicolson Lond. (1967)

29. Runeson, P., Höst, M.: Guidelines for conducting and reporting case study research in software engineering. Empir. Softw. Eng. 14, 131-164 (2008)

30. Strauss, A.L., Corbin, J.: Basics of qualitative research: Grounded theory procedures and applications. Sage Publications, Newbury Park, CA (1990)

31. Hoberg, P., Wollersheim, J., Krcmar, H.: The business perspective on cloud computing-a literature review of research on cloud computing. (2012)

32. Bazarhanova, A., Yli-Huumo, J., Smolander, K.: Love and Hate Relationships in a Platform Ecosystem: A case of Finnish Electronic Identity Management. In: Proceedings of the 51st Hawaii International Conference on System Sciences (2018)

33. Anthes, G.: Estonia: A Model for e-Government. Commun. ACM. 58, 18-20 (2015)

34. Iyer, B., Henderson, J.C.: Preparing for the future: Understanding the seven capabilities cloud computing. MIS Q. Exec. 9, (2010)

35. Schneider, S., Sunyaev, A.: Determinant factors of cloud-sourcing decisions: reflecting on the IT outsourcing literature in the era of cloud computing. J. Inf. Technol. 31, 1-31 (2016)

36. Saya, S., Pee, L.G., Kankanhalli, A.: The Impact of Institutional Influences on Perceived Technological Characteristics and Real Options in Cloud Computing Adoption. In: ICIS. p. 24 (2010)

37. Teece, D.J., Pisano, G., Shuen, A.: Dynamic Capabilities and Strategic Management. Management. 18, 509-533 (2008)

38. Dreyfus, D., Iyer, B.: Managing architectural emergence: A conceptual model and simulation. Decis. Support Syst. 46, 115-127 (2008)

39. Boland, R.J., Lyytinen, K., Yoo, Y.: Wakes of Innovation in Project Networks: The Case of Digital 3-D Representations in Architecture, Engineering, and Construction. Organ. Sci. 18, 631-647 (2007)

40. Lyytinen, K., Yoo, Y., Boland, R.J.: Digital product innovation within four classes of innovation networks. Inf. Syst. J. 47-75 (2015)

41. Eisenhardt, K.M., Martin, J.A.: Dynamic Capabilities: What Are They? 1121, 11051121 (2000)

42. Benlian, A., Hess, T., Buxmann, P.: Drivers of SaaS-adoption-an empirical study of different application types. Bus. Inf. Syst. Eng. 1, 357 (2009)

43. Santos, F.M., Eisenhardt, K.M.: Constructing Markets and Shaping Boundaries : Entrepreneurial Power in Nascent Fields. Acad. Manage. J. 52, 643-671 (2009)

44. Maxwell, J.A.: Understanding and Validity in Qualitative Research. Harv. Educ. Rev. Camb. 62, 279 (1992)

45. Evans, P.C., Basole, R.C.: Revealing the API ecosystem and enterprise strategy via visual analytics. Commun. ACM. 59, 26-28 (2016) 